\title{
Genero desadostasuna Haur Hezkuntzan. Irakasleon erronka berria
}

Maite Gorrotxategi Pereda

Hezkuntza eta Kirol Fakultatea Euskal Herriko Unibertsitatea UPV/EHU

Amaia Alvarez Uria

Hizkuntzaren eta Literaturaren Didaktika Saila

Hezkuntza eta Kirol Fakultatea Euskal Herriko Unibertsitatea UPV/EHU

DOI: $10.1387 / \tan$ tak.17867

GAKO-HITZAK: genero identitatea, genero (arauekiko) desadostasuna, sexu eta genero aniztasuna, binarismoa, haur hezkuntza, gradu amaierako lana.

\section{SARRERA}

Esku artean duzun lan honetan, Haur Hezkuntzako irakasleek genero eta sexu aniztasunari buruz duten ezagutza aztertu dugu. Hori horrela izanda, lana hiru atal nagusitan banatuta dago, batetik atal teorikoa, bestetik, ikastetxean egondako hilabeteetan zehar egindako gaiaren diagnosia elkarrizketa, galdetegi eta behaketaren bidez, eta bertan agertutako ezagutza eta baliabide urriei erantzuna emateko asmoz, guraso zein irakasleentzat baliagarria izateko prestatutako materiala. Hasteko, gaiaren justifikazioa eta egungo egoera azalduko dira. Honen ostean, lan honen bitartez lortu nahi diren helburuak eta informazioa eskuratzeko erabili diren tekniken azalpena agertuko dira. Jarraian, egindako behaketa, galdetegi eta elkarrizketa sakonetik lortutako emaitzak eta hauen interpretazioetatik ateratako ondorioak egongo dira. Ondoren, guraso zein irakasleek gaia jorratu ahal izateko bilatutako material sorta bat, eta azkenik, lan hau burutzeko erabili diren erreferentzia bibliografikoak.

Artikulu honekin sexu eta genero aniztasunak daukan garrantzia azpimarratu nahi dugu. Aurreiritziak gaindituz zein begirada aldatuz jendartean nagusi den binarismoa alde batera utzi eta generoa malgutasunez irudika- 
tzeko. Izan ere, lan honen helburuetako bat horixe izango litzateke, Haur Hezkuntzako irakasleei ikusaraztea zer nolako garrantzia duen aniztasuna kontuan hartu eta errespetatzeak pixkanaka-pixkanaka haurren etorkizunak ikuspegi zabal eta koloretsuagoa izan dezan.

\section{GENERO DESADOSTASUNA ETA SEXU-GENERO ANIZTASUNA}

Gure jendartea etengabe aldatzen doa eta hezkuntza sistema aldaketa horien isla da. Izan ere, aldaketei erantzuna ematen ahalegintzen da errealitatera ahalik eta hobekien egokitu ahal izateko. Egun, jendartean gizonemakumeen arteko eskubide berdintasunaren aldeko kezka handitzen doa eta horren ondorioz, asko dira haien praktika aztertu eta pixkanaka-pixkanaka beraien egunerokotasunean moldaketak txertatzen hasi diren irakasle zein eskolak. Hortaz, irakasleak generoaren gaiarekin arduratuta eta inplikatuta daudela ikus daiteke. Arazoa jendarteak ezagutzen ez dituen edo ezkutuan uzten ahalegintzen den gaiekin sortzen da, horren adibide izango litzateke sexu eta genero aniztasunaren gaia edo ikuspegia.

Termino horiekin erreferentzia egiten zaie generoarekin loturiko arauak betetzen ez dituzten pertsonei, edo trans* pertsonei. Jendearen gehiengoak jaso duen hezkuntza eta bizi izan duen sozializazioa jendarte patriarkalak baldintzatua egon denez, hetero-araua nagusitu da gehiengoaren ideologian, eta horrek, gainontzeko errealitateak ezkutatzea, baztertzea eta gutxiestea ekarri du (Gallardo eta Escolano, 2009). Hori dela eta, egungo mendebaldeko jendartean populazioaren gehiengoak trans* pertsonei buruz duen informazioa oso murritza eta azalekoa da.

Trans* pertsonekiko ezagutza gehienetan estereotipoetan oinarriturik egoten da eta horren ondorioz, jendarteak sortu dituen aurreiritzi ezkorrak barneratu eta genero arauak betetzen ez dituzten pertsonekiko mespretxu eta bazterkeriako jarrerak izaten dira (Gallardo eta Escolano, 2009). Trans* pertsona helduekiko aurreiritziak dauden bitartean, generoaren arauak betetzen ez dituzten haur eta gazteak erabat ezezagunak dira. Hots, jendeak ez daki, eta askotan ez du sinesten, badaudela egokitu zaien generoarekin gustura sentitzen ez diren haurrak. Ezjakintasun horrek, horrelako sentimenduak dituzten eta jarreren bitartez azaleratzen dituzten haurrak baztertzea eragiten du, arraroak izango balira bezala tratatuz.

Jendartean nagusituriko ezjakintasun horren ondorioz, generoaren arauak betetzen ez dituzten haurren egoera latza da, eta ez bakarrik gainontzeko haurren bazterketa jasaten dutelako, baizik eta askotan inguruko helduek ere jarrera desegokiak izaten dituztelako. Jarrera horiek gehienetan oharkabeak izaten dira, zer egin ez jakitearen ondoriozkoak, baina, hala ere, haurrarentzat erabat kaltegarria da bere erreferentziazko pertsonek, guraso zein irakasleek, egoera ulertzeko eta behar besteko laguntza emateko aukerarik ez edukitzea (Härkönen in Paechter, 2007). 
Helduen eragina zenbatekoa izan daitekeen ulertu ahal izateko, garrantzitsua da ulertzea noiz eta nola garatzen den genero identitatea. Izan ere, genero eta sexuarekin erlazionaturiko ekintzak edo sentimenduak helduaroarekin lotzen ditugun arren, genero identitatea jaio aurretik garatzen hasten da. Hau da, medikuak ekografiaren bitartez haurrak organo genital maskulinoak edo femeninoak dituela adierazten duen unean generizazio prozesuari ekiten zaio. Izan ere, medikuak esandakoan oinarrituta, haurraren gurasoak hainbat espektatiba eta aurresuposizio garatzen hasten dira, jendartean nagusi diren genero rolekin lotuta. Horren ondorioz, haurrei beraien genitaletan oinarrituta trataera desberdina ematen hasten dira, bai hitz egiteko orduan, bai jostailuak hautatzerako orduan eta baita arropa aukeratzean ere.

Honen atzetik jendartean nagusi den ikuspegi binarista edo dikotomikoa dago. Ikuspegi honen arabera, sexua eta generoa elkarri loturik daude eta banaezinak dira, hortaz, zakila edukiz gero mutila zara eta alua baduzu, aldiz, neska, soilik bi aukera ezberdin edukiz. Banaketa horretan oinarrituta, helduak jendarteak genero bakoitzari esleitu dizkion rolak erreproduzitzen hasten dira. Horren ondorioz, haurrak jaiotzen direnetik mutil eta nesken arteko desberdintasunak hautematen hasten dira eta oharkabean ideia horiek barneratuz joaten dira (Lewis in Sánchez, 2009).

Ikusten denez, sexua biologikoa den bitartean, generoa eraikuntza soziala da, eta soziala den heinean, beste pertsonekin kontaktuan gaudenean garatzen da. Hori dela eta, haurraren guraso zein irakasleek gaiaren inguruan dituzten ezagutzak erabakigarriak izango dira haurraren garapenean. Izan ere, haurrek beraien bizitzako lehenengo urteetan imitazioaren bitartez ikasten dute eta beraien sozializazio gune nagusiak diren familia eta eskolako helduak hartzen dituzte eredutzat. Hori dela eta, ezinbestekoa da haurren irakasleek genero desadostasuna zer den eta nola hauteman daitekeen jakitea alde batetik, ikasgelan egoera horretan aurkitzen den ikasle bat edukiz gero nola lagundu jakin ahal izateko. Eta bestetik, pixkanakapixkanaka sexuan oinarritutako binarismoa alboratu eta generoa aniztasunaren ikuspegitik jorratu ahal izateko, gure gorputzak ez gaituela mugatzen ulertu ahal izateko (López, 1984).

Artikulu honen gai nagusia den «genero desadostasuna» edo «genero arauekin bat ez etortzea» zer den ulertu ahal izateko, lehenik eta behin argi eduki behar da zein den sexuaren eta generoaren arteko desberdintasuna, ez baitzaio errealitate berdinari interpretazio bera ematen ikuspegi edo begirada desberdinetatik begiratzerakoan. Gerard Coll Planas soziologoaren hitzetan sexuak, jendartearen ikuspegiaren arabera, ar eta eme gisa sailkatzen gaitu, eta gure gorputzen ezaugarri biologikoak dira (kanpo zein barne organo genitalak, bigarren mailako ezaugarri sexualak, kromosomak eta hormonak) eraikuntza honen erantzuleak. Generoak aldiz, erreferentzia egiten die sozializazioaren bitartez pertsonei beraien sexuan oinarrituta esleitzen zaizkien rol jakinei eta honen ondorioz jokatu behar diren jarrera eta jokaera konkretuei (Coll-Planas, 2013). 
Azalpen horren arabera, sexua fisikoa da, gorputzarekin du zerikusia, eta generoa soziala, gainontzeko pertsonekin kontaktuan egonda garatzen da jendarteak sexu bakoitzari esleitzen dizkion rol eta estereotipoen bidez. Aldi berean, generoa botere soziala denez, pertsonak hierarkia sozialean kokatzeko tresna ere bada (Butler, 2013).

Hau da, txikitatik genero bakoitzari ekintza eta jarrera batzuk dagozkiola barneratzen hasten gara eta horiek erreproduzitzen hasten gara (errepikatuz eta barneratuz, gure eginez). Hori dela eta, generoarekin loturiko hainbat ideia eta aurreiritzi garatzen ditugu, diskurtso bat eta praktika batzuk, eta sexua eta generoa elkarri loturik daudela sinesten dugu, hortaz, organo genital maskulinoak dituzten haurrak mutil maskulinoak izan behar direla sinesten dugu eta organo genital femeninoak dituzten haurrak aldiz, neska femeninoak.

Sexua eta generoa deskribatu ondoren genero identitateari buruz bi hitz esan behar ditugu. Genero identitatearen eraketa haurtzaroan hasten da haurrak bere buruaren kontzeptua garatzean eta bere gorputza deskubritu eta honekiko jarrera bat hartzean (gorputza zer den, nolakoa den, berea eta besteena, honen aukerak eta mugak, zein genero esleitu zaion) (Becerra eta Melo, 2012).

Genero identitatearen kontzeptuak dituen bi zatiei begiratuko diegu jarraian. Generoa estatus eta botere harremanak antolatzen dituen sistema soziala da. Genero sistemak lan egiten du bere sistema ekoiztu eta mantentzeko maila soziokulturalean, maila interakzionalean, eta maila indibidualean (Crawford eta Chaffin, 1997). Ikertzaile hauen ustez, ikergaia ez litzateke izan behar gizon-emakumeen arteko desberdintasunak zeintzuk diren jasotzea genero eta feminismo gaiei buruz ari garenean, baizik eta desberdintasuna - diferentzia, hierarkia - nola sortzen eta justifikatzen den ordena sozial generizatu baten gisa (Crawford eta Chaffin, 1997). Identitateari gagozkiolarik esan dezakegu identitatea prozesu gisa edo egitura gisa defini daitekeela. Nork bere jokaera eta egoera animikoa kontzeptualizatu eta kategorizatzeko prozesua da, edo nork bere burua definitzeko erabiltzen diren kontzeptuen egitura, gainera, autoezagutza eta elkarreraginaren bidez gertatzen da identitatea eskuratzea (Becerra eta Melo, 2012).

Genero arauekin bat ez datozen haurrek ordea, generizazioarekin lotutako aurreiritzi eta arau sozialak apurtzen dituzte, izan ere, ez dira jaiotzean esleitutako generoarekin gustura sentitzen. Hau da, organo genital femeninoak eduki arren, mutil sentitzen dira edo alderantziz, organo genital maskulinoak edukita neska sentitzen dira. Edo ez bata eta ez bestea. Kontuan izan behar dugu, generoa soziala den neurrian historikoa ere badela, eta horrek esan nahi duena da ohikotzat ditugun genero portaerak eta genero ereduekiko atxikimendu gradua denborarekin aldatzen direla. Izan ere, $\mathrm{XX}$. mendearen bigarren zatian genero roletan inoiz baino aldaketa azkarragoa egon da (Menvielle, 2003), eta mende aldaketarekin areagotu egin da. 
Honen ondorioz, kontuan izan beharko genituzke belaunaldi berrietan agertzen diren genero adierazpen desberdinak, arauetatik irteten direnak barne. Baina ez da horrela izaten, estigma sozialak 'ez zara gutako bat' esaten diolako haurrari. Inguruneak hainbat modutan bihurtzen ditu ume hauek zaurgarri. Baina ez daude gaixorik, arrisku talde bat dira. Kaltegarriak izan daitezkeen jokaerak nerabezaroan handituko dira nabarmen, baina haurtzaroan hasten da gai honekiko kezka eta larritasun sakona (Menvielle, 2003).

Hori dela eta, kontuan izan beharko genituzke genero binarismoa edo dikotomia sexuala sozialki onartutako araua dena, edo gizon edo emakume izatea ditugu aukera onartuak, eta bestalde, transexualitatea edo transgeneroa aurreko bi aukera hauen arteko truke edo tarteei gagozkienean (Alvarez-Uria, 2013). Baina aukerak ez dira bi, ezta hiru ere, askotarikoak baizik.

Jendartean aukera aniztasun honen aurrean dagoen ezjakintasuna dela eta, haurrek beraien sentimenduak ulertzeko ezintasuna edukitzeaz gain, gainontzeko haurrengandik bazterketa pairatzeko arriskua dute, haiek ere egoera ulertu ezin dutelako. Izan ere, aldez aurretik aipatu den bezala txikitatik generoarekin lotutako rolak oso markatuta daude eta haurrek horiek bete behar direla sinisten dute, nahiz eta oharkabea izan. Horren ondorioz, genero arauekin bat ez datozen haurren egoera zaila izan ohi da eta garrantzitsua da inguruko helduek haurrari zer gertatzen zaion ulertzea ahal duten heinean lagundu ahal izateko (Platero, 2014).

Haur hezkuntzan genero arauekiko apurketak nola hauteman daitezkeen jakiteko, DSM-5 liburuan adierazitako irizpideak hartzen dira kontuan. Honen arabera, haurrak egokitutako generoaren eta bizi edo adierazten duenaren arteko desoreka nabarmen bat erakutsi behar du. Sentimendu hori gutxienez sei hilabetetan zehar mantendu behar da eta hurrengo adierazleetatik gutxienez sei erakutsi behar ditu:

- Egokitu ez zaion generoko partaide izateko desio sakona, behin eta berriz beste generoko partaide dela adieraztea edo bere burua mutil/ neska sailkapenetik at kokatzea.

- Mutilengan, itxura fisiko femeninoa erakusteko eta neskei dagozkien arropekin janzteko nahia. Neskengan, mutilena kontsideratzen den arropa soilik erabiltzeko nahia eta femeninoak kontsideratzen diren arropak baztertzeko joera.

- Jolas sinbolikoa burutzean beste generoari egokitzen zaizkion rolak behin eta berriz interpretatzeko nahia.

- Beste generoarekin loturiko jolas, jostailu eta ekintza estereotipatuak hautatzeko joera nabarmena.

- Beste generoko pertsonekin elkartzeko joera.

- Mutilengan, mutilenak kontsideratzen diren jolas, jostailu eta ekintzei uko egitea. Baita ekintza oldarkorrak erabat ekiditeko joera edu- 
kitzea ere. Neskengan, femeninoak kontsideratzen diren ekintza, jolas eta jostailu estereotipatuekiko erabateko bazterketa eta jokaera maskulinoen agerpena.

- Norberaren gorputzarekiko gorrotoa.

- Beste generoari dagozkion ezaugarri sexualak edukitzeko premia (Platero, 2014: 108-111).

Ikusten denez, oso garrantzitsua da haurrei hitz egiten eta beraien sentimenduak azaleratzen uztea, izan ere, era horretan bakarrik edukiko dugu aukera zer sentitzen duten jakiteko, diren bezala onartu eta behar besteko laguntza eskaini ahal izateko. (Platero, 2014). Baina horretarako dauden aukera guztien berri izatea komeni zaigu.

Gaur egungo egoerari erreparatuz gero, azken urteetan egindako hainbat ikerketek agerian uzten dute irakasleek oraindik ere gaiarekiko ezagutza eta prestakuntza falta handia daukatela. Hala nola Sanchez Sainzek koordinatutako lanean hurrengoa esaten du Belen de la Rosak:

En muchas ocasiones el profesorado no enseña lo que no sabe, lo que desconoce, por ese motivo es tan importante dotar de recursos y herramientas que ayuden a la formación de los docentes a ser cada vez más completos en su tarea educativa (de la Rosa IN Sanchez Sainz, 2010:15).

Hala ere, nahiz eta prestakuntza falta nabaria izan, aipatzekoa da irakasleen gehiengoak genero desadostasuna Haur Hezkuntzatik lantzearen aldeko jarrera erakusten duela. Hori dela eta, oraindik ere ibilbide luzea egin behar dela argi egon arren, etorkizunak ikuspegi baikorra eskaintzen duela esan daiteke.

Eskolaren garrantzia eta eragina oro har berebizikoa da gutxiengo desberdinetako haurren integraziorako eta genero desadostasuna agertzen dutenena ziurtatzeko are gehiago (Bronfman eta Martinez, 1996). Izan ere, genero eredu kulturalen transmisioan hezkuntza da oinarrizko zutabeetako bat, eta ikastetxeek aukera ematen dute eraldaketa hezitzaile eta sozialak egiteko. Horretarako irakasleek genero eta parekidetasun gaietan duten kontzientzia eta prestakuntza gakoak dira (adibidez, transmititzen dituzten estereotipoekin) (Colás eta Jiménez, 2006).

Genero identitatearen adierazpenari begira, feminitatearen eraikuntza ez da emakumeena soilik ezta maskulinitatearen garapena gizonena ere, beraz, edozeinek edozein genero performatu eta eraldatzeko proposamenak egin ditzake, duen generoa duela (Halberstam, 2008). Horregatik pertsona bakoitzak bere gorputza, bizitza eta bizimoduarekin nahi duena egiteko unea dela uste dugu, Sanchez-Sáinzekin batera (2010). Horretarako hezkuntza planetan aniztasun era guztietako edukiak txertatu behar dira.

Esan bezala, eskubide eta aukera berdintasunaren alde egiteko unea da hezkuntzan, aldaketa eta irekiera soziala lortzeko. (Sanchez-Sáinz, 2010). 
Eta horretarako queer teoriak Haur Hezkuntzako irakasleei lagundu ahal die genero estereotipoak beste modu batean ulertzen eta auzitan jartzen. Queer-ek arraro esan nahi du, genero adierazpenetan «normaltasuna» badela ezbaian jartzen duelako. Queer begirada erabili daiteke haurren jolasak birpentsatu, kritikoki pentsatu eta eragiteko gaitasuna duen praktika hezitzailea garatzeko (Blaise eta Taylor, 2012).

\section{HELBURUAK}

Lan honen bitartez, Haur Hezkuntzan genero eta sexu aniztasunarekin loturiko alderdi desberdinak aztertzea dugu helburu.

- Haur Hezkuntzan eman daitezkeen genero arauekiko apurketei buruzko diskurtsoa, teoriak eta ikerketa ezagutzera ematea.

- Etorkizunean haurrei generoa ikuspegi anitz batetik irakasteko informazio eta baliabide egokiak eskura ipintzea.

- Praktiketako ikastetxean lanean HHn ari ziren irakasleek gaiarekiko zuten ezagutza, kontzientzia eta inplikazio maila aztertzea, sexu-genero aniztasunaren ikastetxeko egoera ezagutzeko.

- Elkarrizketa eta galdetegien bitartez ikastetxeko irakasleei gaiari buruzko kontzientzia hartzen laguntzea, bere jarduna aztertu eta egoerarekiko inplikazioa gara dezaten.

- Sexu-genero aniztasuna eta genero arauen apurketak ikasgelan haur guztiekin lantzeko, zein genero arauak apurtzen dituen haurren familiekin lanean aritzeko baliabideak eskaintzea ikastetxeko irakasleei.

\section{METODOA}

\section{Partaideak}

Lan hau aurrera ateratzen lagundu duten pertsonak, 2015-2016 ikasturtean Nafarroako ikastetxe publiko bateko Haur Hezkuntzan lanean ari diren 5 irakasle eta 5 urteko 19 haurrez osaturiko ikastaldea izan dira.

Behaketa haur guztiekin egin zen arren, arreta bereziki haur batengan zentraturik egon zen, izan ere, haur honek ez zituen generoarekin lotutako arauak errespetatzen. Hori dela eta, bere jarrera eta adierazpenak zehazki aztertu ziren. Bestalde, haur honek ikasgelako gainontzeko haurrekin zein irakaslearekin zituen interakzioak aztertu ziren taldearen onarpen maila ikusi eta irakaslearen jarrera nolakoa zen hauteman ahal izateko. Beraz, ikastalde osoa behatu zen, aipatutako haurra, generoa malgutasunez bizi zuen umea, abiapuntu harturik. 
Irakasleei dagokienez, aipatutako taldeko tutorea eta HH-ko gainontzeko 4 tutoreak desberdindu beharko lirateke. Izan ere, talde honen tutorearen kasuan, aurrez aurreko elkarrizketaz gain, bere jarduna zuzenean behatzeko aukera egon zen bitartean, gainontzeko tutoreekiko harremana galdetegi batera besterik ez da mugatu. Azkenik, aipatzekoa da irakasle guztiak 36-56 urte bitarteko emakumeak zirela, hau da, irakasleen lagina nahiko homogeneoa izan zen.

\section{Tresnak}

Hiru tresna metodologiko erabili dira lan hau burutzeko: Irakasleei egindako galdetegia, irakasle-tutoreari egin zitzaion elkarrizketa sakona eta ikasgelan egindako behaketa eta idatzitako egunerokoa.

Beharrezko informazioa eskuratu ahal izateko, metodo kualitatiboko hiru teknika desberdin baliatu dira. Irakasleak zein gainontzeko ikasleek haur honekiko zituzten jarrerak behatzeko, ikasgela barruko behaketa egin zen. Gaiarekiko irakasleak zuen formakuntza eta interes maila ezagutzeko, elkarrizketa sakona egin zitzaion. Eta azkenik, ikastetxeko Haur Hezkuntzako gainontzeko irakasleek gaiarekiko zuten inplikazio eta informazio maila ondorioztatzeko, galdetegiak egin zitzaizkien.

Metodo kualitatiboak ikerketa sakona eskatzen du, arazoa zein den identifikatzeaz gain, aztertzailea arazoan murgiltzen da, hau da, egoeraren muina bilatzen ahalegintzen da ikusten duenari esanahia eman eta interpretazio egokia eskaini ahal izateko. Izan ere, ekintza sozial zehatzen esanahia ezartzen da egileek ematen dieten zentzuari begira, eta gertaera honek jendarteari buruz erakusten duena adierazten du (Olabuénaga, 2009).

Ikastetxeko Haur Hezkuntzako 5 irakasleek bete zuten galdetegiak hiru atal nagusi zituen eta hurrengo galderek osatzen zuten:

\section{Gaiaren Kokapena:}

1. Zuretzat zer da generoa?

2. Eta genero identitatea?

3. Nola lotuko zenituzke generoa eta aniztasuna?

4. Irakasle izanik eta hortaz hezkuntzan eragile garrantzitsua.... Inoiz hausnartu duzu generoaren identitatearen garapenari eta honetan eragina duten faktorei buruz?

5. Gure kulturan, hots, mendebaldeko kulturan, genero arau ugari aurki daitezke. Adibideren bat jarri ahalko zenuke?

6. Genero arauak dauden bezalaxe, badaude arau horiek apurtzen dituzten pertsonak ere. Ezagutzen duzu baten bat?

7. Zuretzat zer da genero arauak apurtzea?

8. Noizbait zalantzan jarri duzu generoen binarismoa, hau da, soilik feminitate eta maskulinitatea existitzea? Gizon eta emakumeez aparte beste zerbait izan gaitezke? Zergatik? 
9. Jaso al duzu noizbait gai honi buruzko formakuntza edo prestakuntzarik, ikasle garaian zein irakasle lanean zaudenetik? ( Ikastaroak, jardunaldiak, liburu edo aldizkariak, lankide, senide edo lagunarteko solasaldiak...).

\section{Esperientzia lan munduan:}

1. Noizbait izan duzu genero arauak apurtzen zituen ikasleren bat ikasgelan?

2. Eduki badituzu, zein baliabide, erabaki, jarrera hartu dituzu?

3. Gainontzeko ikaskideek egoera ondo onartu dute edo genero arauak betetzen ez zituen haurra bazterturik egon da?

4. Eta helduen jarrerak nolakoak izan dira? (beste irakasleak, haurraren gurasoak, gainontzeko haurren gurasoak...)

5. Egun nola ikusten duzu zure burua horrelako egoera bati aurre egiteko? Baliabide nahikoak dituzula uste duzu? Ezagutzen dituzu gai honetan espezializatutako erakundeak?

6. Lan egin duzun ikastetxeetan ikusi duzu gai honekiko inplikazioa? (irakasleen interesa, formakuntza saioak, hitzaldiak, esku-hartzeak, protokoloak, hezkidetza planak...).

\section{Etorkizunari begira:}

1. Garrantzitsua iruditzen zaizu haur hezkuntzan generoaren gaia aniztasunaren ikuspegitik lantzea? Zergatik?

2. Egungo egoera ikusita, zure ustez zer behar da genero arauen apurketa ikastetxeetan lantzeko? (Apurketa auzitan jartzea, gaiaren inguruko informazioa zabaltzea, generoaren gaia aniztasunaren ikuspegitik jorratzea binarismoa alde batera utzita...)

3. Garrantzitsua iruditzen zaizu irakasleek gai honi buruzko informazioa jasotzea eta hausnartzea? Zergatik?

4. Zer gustatuko litzaizuke aldatzea ikastetxean? (Irakasleen jarrera, formakuntza maila, ikastetxearen inplikazioa, baliabideen eskuragarritasuna...).

5. Nire aldetik amaitu dut, eskerrik asko parte hartzeagatik. Badago komentatzeko gogoa duzun zerbait? Esan gabe gertatu zaizun zerbait?

Behaketa lana egiteko aldiz, hiru ardatz izan ziren nagusi:

1. Generoa malgutasunez bizi zuen haurraren adierazpenak (hitzezko zein keinu bidezkoak).

2. Generoa malgutasunez bizi zuen haurrak jolasterako garaian hautatzen zituen jolasak (jostailuak, taldekideak, eta jolasean hartzen zuen rola).

3. Gainontzeko ikaskideek zein irakasleak generoarekin lotuta erakusten zituzten jarrerak (hitzezko zein keinu bidezkoak, generoa malgutasunez bizi zuen haurrarekin edo bestelako uneetan). 
Egunerokoan generoarekin lotutako gertakari adierazgarriak kronologikoki jaso ziren praktikaldiak iraun zuen bitartean eta aurrekoak osatzeko balio izan zuen.

\section{Prozedura}

Gaiari buruzko errebisio bibliografikoa burutu ostean eta ikastetxera heldu aurretik, irakasleek gaiarekiko duten ezagutza eta inplikazio maila praktikan aztertzeko prozesua abiatzeari ekin zitzaion. Hala ere, praktikak hastean, ikastaldean jendarteak ezartzen dituen genero arauekin bat ez zetorren haur bat ezagutzean, ikerketaren barruan behaketa sartzea erabaki genuen, irakasleek generoarekiko eta bereziki genero arauen apurketekiko duten ezagutza eta tratamendua aztertzeaz gain, praktiketako tutoreak haur jakin honekiko zuen jarrera aztertuz. Aldi berean, haur honek taldean jokatzen zuen papera eta besteekin zituen harremanak aztertu ziren. Hortaz, bi ildo desberdin aipatu beharko lirateke, batetik, irakasleek teoria mailan duten ezagutzaren analisia, eta bestetik, praktikan haur jakin honekiko behatutako jarrera eta jokaerak.

Behaketa, egunerokotasuna ezagututa, txokoak eta psikomotrizitate saioak aztertuta egin zen, horiek baitziren haurrek libreki adierazteko zituzten unerik aproposenak. Arreta genero arauak betetzen ez zituen haurraren jarreran eta gainontzeko ikaskide zein irakaslearekiko hartu emanetan zentratu zen eta kontuan hartu ziren irizpideak, genero estereotipoekin lotutako adierazpen fisiko zein hitzezkoak izan ziren. Hau da, behaketaren momentuan haurrak bere buruari erreferentzia egiteko erabiltzen zituen terminoak arretaz entzun ziren, berak bere burua izendatzeko zein genero hautatzen zuen eta horren aurrean irakasleak zein ikaskideek zer nolako erantzunak ematen zituzten aztertzeko. Aldi berean, haurraren jolasak eta keinuak aztertu ziren, jendartean ume honi esleitutako generokoak ez direla kontsideratzen diren ezaugarriak azaleratzen zituen behatu eta adierazpenekin bezala, gainontzekoek horren aurrean ematen zituzten erantzunak hauteman ahal izateko. Horretarako, eguneroko bat erabili zen, egunean gertatutako gertaera aipagarrienak bertan jaso eta ondoren ondorioak atera ahal izateko.

Behaketa abenduaren 9tik urtarrilaren 22ra bitartean burutu zen, hiru astez, nahiz eta aldez aurretik era informalean behatzen hasita egon.

Elkarrizketa eta galdetegiei dagokienez, tutoreari elkarrizketan egindako galderak eta gainontzeko irakasleei emandako galdetegietan agertzen zirenak berdinak ziren. Izan ere, bi kasuetan lortu nahi zen informazioa berdina zen. Metodo desberdina erabili izanaren arrazoia irakasleekiko harremana eta hauen izaeran oinarritu zen. Hau da, tutorearekin izandako harremana zela eta, gertutasun nahikoa geneukan elkarrizketa era eroso batean egin ahal izateko egoerak eragin dezakeen urduritasuna alde batera 
utzita. Gainontzeko irakasleekiko harremana, aldiz, mugatuagoa izan zen, eta aurrez aurreko elkarrizketa batek urduritu eta erantzunak baldintzatzea eragin zezakeela kontuan hartuta, galdetegiak erabiltzea egokiagoa zela otu zitzaigun.

Galdetegiak hiru ataletan banatu genituen, sailkapen honen bidez, irakasleek gaiaren inguruan zituzten ezagutza, bizipen eta espektatibak aztertu nahi izan genituen egoeraren ikuspegi orokor eta osatu bat izateko. Hau da, gure ustez, egoera berri bati aurre egin ahal izateko, lehenik eta behin egoera ezagutu eta onartu beharra dago zer gertatzen den ulertu eta aurre nola egin jakiteko eta horretarako, ezinbestekoa da gaiaren inguruan dagoen informazioa irakurtzea. Hori dela eta, galdetegiaren lehen atalean, gaiaren inguruko ezagutza maila nolakoa zen jakiteko galderak egin genituen.

Bestalde, argi dago gure bizipenek mugatu egiten gaituztela eta askotan nahiz eta egoera gero eta ohikoagoa izan guk edo inguruko norbaitek bizi arte ez dugu horri buruzko inolako galderarik planteatzen. Hori jakinik, lanean izandako esperientzia aztertzeko galderak egin genituen bigarren atalean.

Azkenik, behin esperientzia edukita eta egoera zein den onartu eta ulertutakoan, berebizikoa da norberak aldatu eta hobetzeko nahia izatea egoerak hobera egin dezan. Hori dela eta, etorkizunari begira irakasleek zer nolako espektatibak zituzten aztertzeko, hainbat galdera prestatu genituen hirugarren atalean.

Tutoreari eginiko elkarrizketa urtarrilean burutu zen bitartean, gainontzeko irakasleei galdetegiak aurreko abenduan eman genizkien galderak lasaitasunez aztertu eta sakonki erantzuteko aukera izan zezaten.

Datu guztiak jaso ondoren, datuen analisi eta interpretazioari ekin zitzaion.

\section{EMAITZAK}

Metodoaren atalean azaldu den moduan, informazioa eskuratzeko hiru baliabide desberdin erabili dira, behaketa zuzena, elkarrizketa formala eta bakarkako galdetegi anonimoak. Hurrengo orrialdeetan zehar, horien bitartez eskuratutako emaitzak azaleratuko dira. Bi atal nagusitan banaturik egongo da. Alde batetik, haurraren tutoreak elkarrizketan adierazitakoa azalduko da behaketaren bidez lortutako informazioarekin alderatuz. Eta bestetik, ikastetxeko gainontzeko lau irakasleek emandako erantzunak azaleratuko dira.

Hasieran eginiko galderak irakasleek gaiarekiko zuten ezagutza aztertzera bideraturikoak izan ziren, hortaz, atal teorikoarekin eta norberaren ideia propioekin loturiko datuak izango dira hasieran agertuko direnak. Bigarren atala norberaren esperientzia pertsonalarekin loturikoa da. Hau da, 
gaiarekin lotuta klasean izandako esperientziekin erlazionatutako datuak izango dira. Azkenik, hirugarren atalean egungo egoera hobetzeko asmoz haien ustez zer nolako aldaketak eman beharko liratekeen galdetu zitzaien, beraz, aurreikuspen eta desioekin lotutako emaitzak izango dira.

\section{Tutorearekin elkarrizketa}

Emaitzen deskribapenarekin hasteko, lehenik eta behin genero arauekin bat ez zetorren haurraren tutoreari egindako elkarrizketa aztertuko da ikasgelan ikusitakoarekin alderatuz.

Hasieran egindako galdera teorikoei erreparatuz, aipatzekoa da nabaria zela gaiaren inguruan informazioa irakurrita zeukala, emandako erantzunak sakonak izan zirelako. Hala nola «zer da generoa» galderari «neskal mutil, emakume/gizon bezala identifikatzen gaituen estatus soziala» erantzun zion. Hortaz, agerian geratzen da ez dela bat-bateko erantzun subjektibo bat, aldez aurretik informatu izanaren ondorioa baizik.

Genero arauei buruz galdetzean, hau izan zen emandako erantzuna: «nahiz eta aurrerapenak egin, oraindik ere jendeak neskak eta mutilak koloreen eta jostailuen arabera ezberdintzen ditu, hortaz, argi dago emandako aurrerapausoak ez direla behar bezain handiak izan».

Honen bidez agerian geratzen da irakasle honek jendartean dauden generoarekin loturiko estereotipoak ezagutzen dituela. Gainera, binarismoari buruz galdetzean, hauxe erantzun zuen: «gaur egun gauza guztiei etiketa bat edo izen bat jarri nahi diegu, baina agian dena izendatzearen tendentzia hori alde batera utzi eta bakoitzak nahi duena izan beharko luke inork galderarik egin gabe, ez?» Emandako bi erantzun hauen bidez, nabarmendu egiten da genero arauak ekiditearen garrantziaz ohartzen dela.

Ikasgelako jarduna aztertzean, hori agerian geratzen zen hizketaldietan zein haurrekin zuen jarreretan. Izan ere, ez zuen desberdintasunik egiten koloreen erabileran zein jostailuen esleipenean. Genero arauekin bat ez zetorren haurraren kasuan, irakaslea kontziente zen haur horrek behin eta berriz femeninoak kontsideratzen diren jostailu, kolore zein jarrerak izaten zituela, baina ez zion inolako eragozpenik jartzen. Are gehiago, haur honek euskaraz hitz egiteko zailtasunak zituenez, behin eta berriz gaztelaniaz aritzen zen eta jolasetan bere burua izendatzeko hitz femeninoak erabiltzen zituen, hala nola, «princesa», «una modelo», «una bailarina», ... eta irakasleak ez zion zuzentzen, libreki adierazten uzten zion.

Nahiz eta libreki adierazten uzten zion, horrek ez du esan nahi arretarik eskaintzen ez zionik, izan ere, haurrak etxean bera zergatik zen mutila galdetu zuela jakin zuenetik, arreta berezia eskaintzen zion haurrak egindako galderei edo bere gorputzari buruzko adierazpenei. «Ikasgelan adi egon gara horrelako adierazpen edo galderak egiten zituen hautemateko, adibi- 
dez, gorputza lantzean, baina berak ez du inoiz adierazi horrelakorik. Hala ere, beti arreta mantentzen diozu, zerbait hautemanez gero laguntzeko.»

Hala ere, aipatzekoa da eguneroko errutinetan matematika zein haurren izenak lantzean, klasera nor etorri den eta nor ez jakiteko ikasleen zerrenda irakurtzen zutela. Zerrenda amaitzean, etxean geratutako haurrak neska eta mutiletan sailkatzen zituzten batuketak lantzeko asmoz. Horretarako mutil baten eta neska baten irudiak erabiltzen zituzten haurrek zenbakiak non jarri behar zituzten ikasteko. Irudi horiek aztertuz gero, binaristak izateaz gain, nahiko estereotipatuak zirela esan daiteke, izan ere, neska irudikatzeko ile luzea eta soinekoa zeramatzan marrazki bat zuten eta mutila irudikatzeko aldiz, ile motza zuen eta arropa urdina zeraman marrazki bat zuten.

Elkarrizketako bigarren atalean, ikasgelan genero arauak betetzen ez zituen haurrarekin izandako esperientziari buruzko galderak erantzun zituen tutoreak.

Bereziki azpimarratu zuen formakuntza aldetik zein baliabide aldetik falta nabaria sentitzen zuela, ikasgelan emandako pauso guztiak bere kabuz bilatutako informazioan eta hartutako erabaki propioetan oinarrituta eman baitzituen. «Duela urte batzuk formakuntza edo ikastaro bat jaso nuen, baina hor geratu zen».

«Baliabideak ez ditugu, beraz, nik gabezia hori nabaritu dut. Egoeraren aurrean zu saiatu behar zara intuizioaren arabera zer egin erabakitzen.»

«Guztiontzat oso lagungarria izango litzateke nolabaiteko laguntzaile bat izatea.»

Bere formakuntzaz gain, gainontzeko haurrek haur honekiko zituzten jarrerei buruz hitz egin genuen. Orokorrean haurrek egoera inolako arazorik gabe onartu dutela aipatu zuen, nahiz eta uneren batean, bere gustuekin erlazionatutako aipamenen bat egin. «Taldeko kide bat gehiago da, egia da aldiren batean haurrek komentatu dutela: honek kolore hau erabiltzen du... Une horretan zuk naturaltasunez erantzuten duzu, aizu, kolore hori niri ere gustatzen zait eta haurrek garrantzia kentzen diote.»

Praktiketako egonaldian zehar, haurrek behin baino gehiagotan egin zuten horrelako aipamenen bat eta irakasleak elkarrizketan adierazi zuen bezalaxe, haurrei azaldu zien bakoitzak eskubidea zuela nahi zuen kolorea hautatzeko. Honen adibide bat jartzearren, klasean Elmerren ipuina kontatzen zuten eta bertan elefante grisez gain, bazegoen koloretsua zen beste elefante bat. Horrekin lotuta, Gabonetako jaialdian elefante baten abestia kantatu behar zutenez, elefanteen maskarak margotzeko garaian, irakasleak arrosaz edo grisez margotzeko aukera eskaini zien. Genero estereotipoekin bat egiten ez zuen haurrak inolako zalantzarik gabe berak arrosaz margotuko zuela adierazi zuen. Gainontzeko ikasleetako batzuek aurpegi arraroa jarri zuten eta horretaz ohartuta, irakasleak oso ideia ona zela adierazi zion, horrela aurpegia hobeto ikus zitekeelako eta berak ere arrosaz margotuko 
zuela adierazi zuen. Hori ikusita, gainontzeko haurretako askok ere arrosaz margotu zuten.

Haurren aipamenekin lotuta, irakasleak hauxe adierazi zuen: «sozialki gaia ez dago batere onartuta. Neskak eta mutilak etiketen bidez sailkatzen dituzte. Beraz, nire ustez haurren jarrera horren ondorioa da. Hau da, nire ustez, eragin gehiago dute kanpoko eragile sozialek barruan dugunak baino».

Hori ikusita, haurraren gurasoek zein gainontzeko haurren gurasoek izandako jarrerei buruz hitz egin genuen. Irakasleak adierazi zuenaren arabera, «Behin amak komentatu zidan beraiek zertxobait kezkatuta zeudela umeak galdetu ziolako ea bera zergatik zen mutila eta berari oso zaila egiten zitzaiola horri erantzun ahal izatea».

Hala ere, dagoneko denbora tarte bat pasata eta egoeraren bilakaera ikusirik, oraingo egoerari buruz, hauxe erantzun zuen: «nik uste dut hasierako beldur hori gutxitzen ari dela nolabait eta beraiek ere ikusten ari direla dagoena eta naturaltasun osoz ari direla barneratzen». Eguneroko sarrera eta irteera uneetan, gurasoekin izandako harremanetan nabaritzen zen gurasoek haurra den bezalakoa onartzen zutela, ama bereziki irribarretsu egoten zen haurra dantzan edo jolasean pozik ikusten zuenean. Gainera, etxean ere den bezala izaten uzten diotela aipatu behar da, haurrak kontatzen zigulako, adibidez, amaren makillajea erabiltzen zuela mozorrotu eta modeloek bezala desfileak egiteko.

Gainontzeko gurasoei buruz galdetzean erantzuna antzekoa izan zen: «noski baietz, beraiek argi dute: berak hori erabaki badu guk onartu eta errespetatuko dugu. Haur hau besteak bezain onartuta dago, bai ikastetxean baita ikastetxetik kanpo egiten dituzten ekintza guztietan ere».

Onarpen honen adibide gisa, klaseko neskato baten urtebetetzea aipatzea interesgarria izango litzateke. Urtebetetzea zela eta, neskatoa eskolatik kanpo egingo zen meriendarako gonbidapenak banatzen hasi zen. Gonbidapenak bi koloretakoak ziren, arrosak eta urdinak, banatzen zihoan heinean, erraz ondoriozta zitekeen kolore urdina zutenak mutilentzat zirela eta arrosak aldiz neskentzat. Hala ere, genero estereotipoekin bat egiten ez zuen haurraren kasuan, gonbidapen bat izan ordez, bi izan zituen, gonbidapenak banatzen zituenak esan zuen bezalaxe: «urdina mutila delako eta arrosa kolore hori asko gustatzen zaiolako». Haurra poz-pozik geratu zen bere bi gonbidapenekin, gainera biak elkartzean morea ateratzen zela ikusita liluraturik geratu zen. Gainontzeko ikaskideek ez zuten honen inguruko inolako aipamenik egin.

Elkarrizketaren bigarren atal honekin amaitzeko, egoerari aurre egiteko zituen baliabideei buruz hitz egin genuen, tutoreak bere burua egoerari aurre egiteko prest ikusten zuen edo ez jakiteko. Elkarrizketaren lehen atalean aipatu zuen bezala, baliabide falta azpimarratu zuen berriz ere: $« B a$ liabide aldetik nik gabezia nabaritu dut, zure ardura da materiala bilatzen aritzea... Adibidez, Elmerren ipuinak oso garrantzitsuak dira». Elmerren 
ipuina, aurretik aipatu den bezala, gainontzekoengandik desberdina den elefante bati buruzkoa da. Gainontzeko elefanteek burla egiten diote desberdina izateagatik, baina azkenean elkar onartzen eta aniztasuna errespetatzen ikasten dute guztiek. Ipuina irakurri ostean, haurrek esanahia ondo ulertzeko eta klaseko aniztasuna ikusteko, irakasleak elkarrizketa zein ariketa ugari egiten zituen. Adibidez, altuera desberdina zuten bi edo hiru haurri zutik jartzeko eskatzen zien eta gainontzekoek bakoitza nolakoa zen esan behar zuten (altua, baxua, ertaina...). Horren ostean, irakasleak galdera ugari egiten zizkien, hala nola, «altuagoa izateagatik hobea da?», «iseka egin behar diogu baxua izateagatik?», «besteei burla egin behar diegu desberdinak izateagatik?». Galderekin batera, ipuineko pasarteak aipatzen zituen haurrek loturak errazago ikusi ahal izateko. Izan ere, berak adierazi zuen bezala, «beraiekin hitz egiten duzunean oso ondo ulertzen dute, loturak erraz egiten dituzte, inolako arazorik gabe».

Baliabide faltaz gain, gaiarekiko formakuntza falta ere aipatu zuen gai honetan espezializatutako erakundeak ezagutzen ez zituela adieraziz: «Egia esan, nik ez ditut horretan lan egiten duten erakundeak ezagutzen. Nik uste dut oso garrantzitsua dela formakuntza sakon bat izatea hori izango baita geroz eta pausu ziurragoak ematea ahalbidetuko diguna. Gainera, aurrera baldin bagoaz suposatzen da normaltasun hori eskolaz kanpo ere lortuko dela. Era horretan jendartea pixkanaka-pixkanaka aurrerapausoak ematen hasiko litzateke».

Formakuntza falta aipatzeaz gain, ikusten denez, irakasleek formakuntza saio horiek jasotzeak eragingo lituzketen onurak azpimarratu zituen saio hauen beharra aipatuz.

Bere ezagutza eta formakuntzari buruzko galdera hauen bitartez, elkarrizketaren azken atalari ekin genion, hau da, etorkizunari begira hobetzeko eman beharreko pausoei buruzko galderei, aurreko ideiekin erabat uztartuta baitaude.

Genero arauen apurketa lantzeko beharrezko elementuekin jarraituz, hauxe adierazi zuen: "gauza asko eman behar dira, hala nola gaiaren inguruan hausnartzea eta ohartzea genero arauak orokortasun bat besterik ez direla eta ez dutela aniztasuna kontutan hartzen. Gainera, formakuntza saioak antolatu beharko lirateke irakasle, ikasle eta gurasoentzat». Ikusten denez, formakuntzaz gain, norberaren hausnarketa propioaren garrantzia azpimarratzen du binarismoaren ideia zalantzan jartzeko eta gainditzeko.

Etorkizunari begira egin beharreko aldaketekin jarraituz, norbanakoaren hausnarketa propioaz gain, ikastetxe mailan kontuan hartu beharreko hainbat ideia aipatu zituen: «Nik uste dut baliabideak eskura izan beharko genituzkeela, gainera, ikastetxe mailan hausnarketa bat egin beharko litzateke lehentasunak finkatu eta behar besteko erabakiak hartzeko irakasle, guraso eta ikasleei begira».

Nahiz eta gaia txikitatik jorratzearen beharra aipatu, klasean genero arauekin bat ez datorren ikaslerik eduki ezean generoaren aniztasuna lan- 
duko lukeen galdetzean, hauxe erantzun zuen: «nik pertsona espezializatu baten laguntza izatea nahiko nuke, berari aholkuak eskatu ahal izateko». Honen bidez agerian geratzen da berarentzat gai konplexua dela eta zaila egiten zaiola inolako laguntzarik gabe egoerari aurre egitea. Hala ere, gaia jorratzeko beharra aldarrikatu zuen elkarrizketaren amaieran: «errealitate bat da, beraz, honi aurre egin behar zaio, ezin ditugu begiak itxi».

\section{Galdetegiak}

Dagoeneko elkarrizketa eta behaketaren analisia bukatuta, hurrengo orrialdeetan ikastetxeko Haur Hezkuntzako beste lau irakasleri egindako galdetegien emaitzak azalduko dira.

Aurretik aipatu den moduan, lehenengo galderak gaiarekiko ezagutzekin loturikoak izan ziren, hortaz, gaiarekin loturiko kontzeptu zehatzei buruzko hiru galdera egin zitzaizkien. «Zuretzat zer da generoa?» galderan, irakasle guztiek emakume/gizon edo maskulino/femenino sailkapena aipatu zuten, hau da, sexuan oinarritutako banaketa binarioan oinarrituz erantzun zuten.

Genero identitateari buruzko galderan aldiz, ez da erabateko adostasunik hautematen. Lau irakasleetako bik genero identitatea norberaren pertzepzio, identifikazio, onarpen eta ongizatearekin lotu zuten. Beste bi irakasleek aldiz, jendarteak ezarritako emakume eta gizonen rol estereotipatuekin.

Generoa eta aniztasuna nola lotuko lituzketen galdetzean aldiz, lehenengo galderarekin kontraesana sortu zen irakasleetako baten erantzunean. Izan ere, jendarteak onartzen dituen bi generoez gain gehiago ere badaudela erantzun zuen. Beste bi irakaslek genero bakoitzeko partaide izateak eragiten dituen desberdintasunekin uztartu zuten aniztasuna. Azkenekoak aldiz, aniztasuna genero identitate zein orientazio sexualarekin uztartu zuen.

Hurrengo galderak genero identitatearekin, genero arauekin eta genero arauen apurketekin loturikoak izan ziren.

Genero identitateari dagokionez, honen garapenean eragina duten faktoreei buruz noizbait hausnartu duten galdetzean, bik baietz erantzun zuten eta bik aldiz ezetz. Aipatzekoa da ezetz erantzun zuten biek klasean arauak apurtzen zituen ikasleren bat izan zuten galdetzean ezetz erantzun zutela eta baietz erantzundakoek aldiz, baietz.

Genero arauei dagokienez, hasteko, genero arauen adibideak aipatzeko eskatu nien. 4 irakasleetatik 3k lanaren banaketarekin lotu zituzten genero arauak eta laugarrenak, itxura fisikoarekin lotutako estereotipoekin.

Genero arauen apurketari buruz galdetzean aldiz, 3k jendarteak genero bakoitzari ezarritako estereotipoak ez betetzea dela erantzun zuten, eta laugarrenak aniztasuna ez errespetatzea dela. 
Genero arauekin jarraituz, gizon/emakume sailkapen binarioa noizbait zalantzan jarri duten galdetu zitzaien eta laurek ezetz esan zuten. Hala ere, aipatu beharra dago batek hausnarketarik egin ez izan arren, onartzen duela intersexualak eta transexualak diren pertsonak egonda, bi genero baino gehiago daudela. Eta beste bik aldiz, bi generoen arteko banaketan sinesten duten arren, azpimarratzen dute nahiz eta bi genero egon, genero bakoitza bizitzeko modu desberdinak daudela.

Atal honi amaiera emateko, gaiaren inguruan jasotako informazioari buruz galdetu zitzaien. Galdeketa bete zuten lau irakasleetatik bakar batek aipatu zuen ikasle garaian nolabaiteko formakuntza jaso zuela. Beste hirurek ezetz adierazi zuten, eta hauetatik bakar batek aipatu zituen lankide zein senideekin gaiari buruz izandako solasaldiak.

Hurrengo galderak lan munduan izandako esperientziekin lotutakoak izan ziren, hots, noizbait klasean genero arauekin bat ez zetorren ikasleren bat izan duten eta baiezkoa izatekotan zer nolako jarrerak erakutsi dituzten.

Dagoeneko aipatu dudan bezala, irakasleetako bik bakarrik aipatu zuten noizbait izan dutela genero arauekin bat ez zetorren ikasleren bat eta bien artean desberdintasun nabariak aurki daitezke.

Kasu zehatz horietan erabilitako baliabide eta erakutsitako jarrerei buruz galdetzean, irakasle batek normaltasunez tratatzea besterik ez du aipatzen, hau da, besteekin bezala aritu haurra desberdin sentitu ez zedin. Besteak aldiz, hiru pauso aipatzen ditu: haurraren sentimenduak onartzea, orientatzaileari pautak eskatzea gainontzeko haurrekin zein gurasoekin elkarbanatzeko, eta ikasgelan errespetua lantzea.

Gainontzeko ikaskideek egoeraren aurrean erakutsi zituzten jarrerei buruz galdetzean ere erantzunak erabat desberdinak izan ziren. Haurrarekin normaltasunez aritu zela adierazi zuen irakasleak gainontzeko ikasleek inolako arazorik gabe onartu zutela aipatu zuen. Beste irakasleak aldiz, egoera desberdin bat bizi izan zuen. Kasu honetan biologikoki mutila izan arren neska sentitzen zen 3 urteko haur bat zen. Neskek arazorik gabe onartzen zuten bitartean, mutilek ez zuten onartzen eta iseka egiten zioten.

Helduen jarrerei buruz hitz egitean biek bat egiten dute jarrera ezkorrak eman zirela aipatuz. Klasean arazorik izan ez zuen haurraren kasuan irakasleak gurasoek ezkutuan komentario sexistak egiten zituztela adierazi zuen. Beste irakasleak aldiz, malgutasun eza nagusi zela aipatu zuen, haurraren gurasoen jarrera ere desegokia zela adieraziz.

Atal honi amaiera emateko asmoz, gaur egun egoerari aurre egiteko dituzten baliabideei buruz eta egondako ikastetxeetan nabaritutako inplikazio mailari buruz galdetu zitzaien, eta laurek baliabide zein inplikazio falta azpimarratu zuten.

Galdetegiaren azkeneko atalean, orain arteko egoera ikusita etorkizuna hobetzeko beharrezko aldaketei buruz hausnartzeko hainbat galdera egin zitzaizkien. 
Lehenengo galdera orokorrena izan zen: «Garrantzitsua iruditzen zaizu Haur Hezkuntzan generoaren gaia aniztasunaren ikuspegitik lantzea? Zergatik?» lau irakasleek baiezko erantzuna eman zuten haurrei txikitatik anitzak garela eta aniztasun hori onartzen eta errespetatzen irakatsi behar zaiela argudiatuz.

Azkenik gaiaren garrantziari buruz eta era egokian landu ahal izateko baliabideei buruz galdetu zitzaien. Lauek gaia Haur Hezkuntzatik lantzen hastea garrantzitsua dela aipatzeaz gain, egoera aldatzeko oinarria irakasleek informazioa jasotzea dela azpimarratu zuten. Horri esker hausnarketak egin eta generoa aniztasunaren ikuspegitik landu ahal izateko. Horrekin batera, gaia lantzeko ipuinak, formakuntza saioak eta sentsibilizazio tailerrak aipatu zituzten. Beti ere ikastetxearen inplikazioa ezinbestekoa dela adieraziz.

\section{ONDORIOAK}

\section{Ezagutza teorikoak}

Arlo honetan oraindik ere aurrerapauso handiak eman behar direla esan daiteke, izan ere, generoari buruz galdetzean, galdetutako bost irakasleetatik bakar batek besterik ez zuen aipatu jendartearen eragina, gainontzeko lau irakasleek sexuan oinarritutako ikuspegi binaristan oinarrituz erantzun zuten. Ikuspegi horren arabera, jaiotzez ditugun organo genitalek baldintzatu egiten gaituzte, hortaz, zakilarekin jaiotzen diren pertsonak mutilak dira eta aluarekin jaiotzen direnak neskak. Ez dago beste aukerarik. Hala ere, aipatu behar da, bi genero besterik ez daudela esan arren, genero bakoitza bizitzeko hamaika era daudela defendatzen dutela. Ondorioz, beraien ikuspegi binarista ez litzateke zurruna edo erabatekoa izango. Hala ere, trans* pertsonak eta pertsona intersexualak alde batera uzten dira, existituko ez balira bezala. Pentsamendu honek genero arauekin bat ez datozen pertsonen gutxiespen eta bazterketa dakar. Izan ere, errealitatean horrelako pertsonak badaudela jakin ezean, ezinezkoa izango da normaltasunez tratatuak izatea eta merezi duten errespetu eta onarpena lortzea. Hala ere, ezagutzea aipatzen denean ez zaio erreferentzia egiten horrelako pertsonak badaudela jakite hutsari, beraien errealitatea ezagutzeari baizik. Izan ere, jendartean nagusi diren estereotipoetan oinarrituz gero, trans* pertsonen aurkako aurreiritziak mantenduko lirateke beraien errealitatea zein den jakin gabe eta beraien desabantaila egoera mantenduz (Mcdonough, 2007).

Galdetutako pertsonak irakasleak direla kontuan izanik, are kezkagarriagoa da ezjakintasuna. Izan ere, haurrek helduengandik ikasten dute, eta gurasoekin batera, irakasleak dira haurren erreferentziazko mundua osatzen duten heldurik garrantzitsuenak. Aurretik aipatu den bezala, Haur Hezkuntzako etapan zehar haurrak generoari buruzko ideiak eta bere genero iden- 
titatea garatzen hasten dira. Prozesu horietan guraso eta irakasleen jarrerak, espektatibak eta aipamenak erabakigarriak dira, azken finean, haurrek ideia horiek guztiak jaso eta pixkanaka barneratu egiten dituzte genero bakoitzarekin lotutako hainbat ezaugarri konkretu bereganatuz (Colas \& Jiménez, 2006).

Hortaz, helduek ikuspegi binarista mantentzen badute, oso zaila edo ia ezinezkoa izango da haurrek bere kabuz beste motatako pertsonak egon daitezkeela ondorioztatzea. Azken batean, haurrek helduek esan eta egiten dutenaren arabera osatzen dute beraien mundua. Ondorioz, beraien erreferentziazko pertsonek emakumeak eta gizonak bakarrik ezagutzen badituzte, haurrek ez dute haien iruditeria zabaltzeko aukerarik izango (Winnicott in Talburt eta Steinberg, 2005). Hori horrela izanez gero, genero arauekin bat ez datozen pertsonak egoera gutxituan mantenduko lirateke, ezjakintasunaren ondorioz sorturiko mesfidantza eta mespretxua pairatuz (Green eta Friedman, 2013).

Hori ikusita ezinbestekoa izango litzateke helduei behar besteko formakuntza eta informazioa eskaintzea, orain arte jasotako ideiei buruzko hausnarketa egin, hain barneratuta dauden ideiak zalantzan jarri, eta behar besteko moldaketak egiteko. Ildo honi lotuta, aztertutako ikastetxearen egoera nahiko baikorra dela esan daiteke, azken batean, nahiz eta gaur egun baliabide eta formakuntza falta nagusi izan, genero aniztasunaren lanketari buruz galdetzean, irakasle guztiek garrantzitsutzat hartzen dutela ikus daiteke. Honek bat egiten du Romero eta Abril-ek (2008) egindako ikerketan lortutako emaitzekin. Hau da, ikusten denez, ikastetxeetan oraindik ere ezjakintasuna nagusi da, eta genero identitatearen gaia ez da aniztasunaren ikuspegitik lantzen, baina irakasleek gero eta interes handiagoa daukate eta arlo horretan formakuntza jasotzearen beharra azpimarratzen dute.

$\mathrm{Bi}$ ideia kontrajarri direla pentsa daitekeen arren, ez du zertan horrela izan behar. Kontuan hartu behar dugu 36-56 urte bitarteko pertsonei buruz hitz egiten ari garela. Hortaz, beraiek jaso duten hezkuntza formala, etxeko heziketa, eta beraien jendartea, ikuspegi binarista duen sistema patriarkal baten barnean kokatu beharra dago. Hori dela eta, logikoa da pentsatzea nahiz eta generoari buruzko kezka eduki eta mutil zein nesken estereotipoekin hautsi nahi izan, prozesu hori erabatekoa izatea oztopatzen duten jarrera eta ideiak mantentzen dituztela (Bustos in Malavé, 2012).

\section{Irakasle lanean izandako esperientzia}

Behar besteko formakuntza saioak eta informazioa jasoz gero, irakasleek genero arauen eta hauen apurketen gaiari buruzko ikuspegi askoz ere sakon eta zabalagoa izango lukete, eta horrek ahalbidetuko luke generoaren binarismoa gainditu eta generoa aniztasunaren ikuspegitik jorratu ahal izatea. Kontuan izanda gurasoen jarrerei buruz galdetzean horrelako egoera 
bat bizi izandako 3 irakasleetatik $2 \mathrm{k}$ jarrera desegokiak izan zituztela aipatu zutela, badirudi ikuspegi aldaketa horren ardura ikastetxearen esku geratzen dela. Izan ere, erantzun horiek agerian uzten dute gaur egungo gurasoek oraindik ere rol eta estereotipoen banaketan sinesten dutela eta horiek apurtzeak kezkatu egiten dituela, bereziki mutilek jarrera femeninoak erakusten dituztenean. Hori dela eta, ikastetxean ikuspegia aldatzen ahalegindu ezean, ezinezkoa dirudi haurrek generoen banaketa zurrunean sinesteari uztea (Platero, 2015).

Aldatzeko eta aniztasuna ikasgelan jorratzeko lehenengo pausoa errealitatea ezagutu, onartu eta daukan garrantzia aitortzea da. Aztertutako ikastetxean hori egon badago, baina hanka sartzearen beldurra oraindik handiegia da. Hau da, beraien formakuntza faltaren ondorioz, ez dute beraien burua gai ikusten ikasgelan genero identitatea aniztasunaren ikuspegitik landu ahal izateko, hortaz betiko ikuspegi binarista mantentzen dute. Horren adierazle izango litzateke genero arauak betetzen ez dituen haurraren tutorearen kasua. Nahiz eta gaiaren inguruan informazioa irakurrita eduki eta haurrari den bezala izaten uzten dion, ez du genero identitatea aniztasunetik lantzeko jarduera berezirik egiten. Egia da, aniztasuna lantzeko asmoz Elmerren ipuina lantzen duela, baina horretaz gain, ez du beste jarduera espezifikorik egiten. Gainera, era oharkabean generoekin lotutako estereotipoak igortzen ditu emaitzen atalean aipatutako neska eta mutilen irudi estereotipatuen bidez (klasean ikasleen asistentzia lantzerakoan). Elkarrizketan, sexu eta genero aniztasunaren gaia nahiz eta ikasgelan horrelako kasurik ez eduki landuko lukeen galdetzean, irakasleak adierazi zuen berak nahiko lukeela pertsona espezializatu baten laguntza jasotzea gaia ondo jorratu ahal izateko, orain ez duelako bere burua horretarako gai ikusten. Beraz, agerian geratzen da formakuntzarik jaso ezean, irakasleek ez dutela sexu eta generoaren irakaspena aldatuko, ez nahi ez dutelako baizik eta ez dutelako haien burua gai ikusten (Mayor, 2015).

\section{Etorkizunerako erronka}

Formakuntza hori jaso ahal izateko, ikastetxearen inplikazioa lortu behar da, hau da, ez da nahikoa irakasle batek formakuntza saio bat nahi izatea ikastetxeak hori eskaintzeko, beharrezkoa da zuzendaritza taldeak gai garrantzitsutzat jotzea, ikastaroa eskaintzea beharrezko ikusteko. Honekin lotuta, lan egin duten ikastetxeetan gaiarekiko zein inplikazio maila nabaritu zuten galdetu zitzaien irakasleei eta guztiek inplikazio eza edo urria aipatu zuten. Nahiz eta inplikazio falta azpimarratu, ikastetxe konkretu honen kasuan Haur Hezkuntzako irakasle guztiek gaiaren garrantzia eta formakuntzaren beharra adierazi zuten. Beraz, interesa egonda, pentsa daiteke formakuntza saiorik eduki ez izana eskaera formal bat egin ez izanaren ondorioa dela, eta ez ikastetxeko zuzendaritzaren interes faltagatik. Gainera, 
kontuan hartu behar da Lehen Hezkuntzako ikasleentzat hezkidetzako ikastaroak ematen direla generoa eta sexualitatea lantzeko. Ikastaro edo formakuntzarik eskaini ez izanaren beste arrazoi bat non eskatu ez jakitea izan daiteke, izan ere, gaiarekin erlazionatutako erakundeei buruz galdetzean, irakasleek ez zituztela ezagutzen erantzun zuten. Hortaz, komenigarria izango litzateke ikastetxeek sexu eta generoaren aniztasuna lantzen duten erakundeak ezagutzea haiekin kontaktuan jarri eta behar besteko informazioa jaso ahal izateko.

Hau guzti hau esanda, agerian geratzen da hasieran azaldu den bezala, oro har irakasleek oraindik gaiarekiko ezjakintasun maila altua daukatela eta horren ondorioz, ikastetxeetan genero eta sexu aniztasunaren gaia ez dela jorratzen (Romero eta Abril, 2008).

Hala ere, irakasleen interes maila altua dela ikusita gaia uste baino ezagunagoa dela ikus daiteke. Honetan aipagarria da Chrysallis Euskal Herria erakundeko burua den Mayorrek elkarrizketa batean aipatutakoa. Izan ere, gaur egungo ikastetxeen egoerari buruz galdetzean, irakasleek genero arauak betetzen ez dituzten haurren egoera nolakoa den guztiz ezagutu ez arren, laguntzeko prestutasuna erakusten dutela eta ikasteko jarrera nagusi dela adierazi zuen (Mayor, 2015). Hortaz, ikusten denez ez da soilik aztertutako ikastetxe konkretu honetako egoera, Euskal Herri mailan zabaldutako jarrera bat baizik.

Ezjakintasun eta beldur horiek gainditu ahal izateko, beharrezkoa da ikastetxeek, formakuntzaz gain, haurrekin gaia jorratu ahal izateko materialak edukitzea eta horiek non bilatu ditzaketen jakitea. Hori dela eta, lan honi amaiera emateko asmoz, genero eta sexu aniztasuna Haur Hezkuntzan lantzeko erabilgarriak izan daitezkeen materialen bilduma bat osatu da Haur Hezkuntzako irakasleei begira. Bertan ipuinak, ikus-entzunezko materiala, zenbait jarduera eta elkarteen kontaktuak daude.

\section{IRAKASLE ETA FAMILIENTZAKO MATERIALA}

\section{Haurrentzako ipuin gomendagarrien zerrenda}

Diane Rodríguez, (2015). Benedicto se siente niña. Ekuador: Silueta X.

Christian Bruel eta Anne Galland, (2008). Julia la niña que tenía sombra de chico. Madril: El jinete azul.

Tanía Andrés Heras, (2016). El nombre que se equivocó de niña: Madril: Chrysallis.

María Gutiérrez, (2015). El rancho de Cris. Bartzelona: Bellaterra.

Mar Pavón, (2015). Eso no es normal. Malaga: Nubeocho.

Briggite Minne, (2006). Hadabruja. Granada: BFE.

Raquel Díaz Reguera, (2010). ¿Hay algo más aburrido que ser una princesa rosa?: Bartzelona: Thule. 
Ana Castro, (2015). La gran equivocación. Madril: Chrysallis.

María Gutiérrez, (2015). La mochila rosa. Bartzelona: Bellaterra.

Nunila López, (2012). Los colores (cuentos para antes de despertar). Madril: Planeta.

Cheryl Kilodavis, (2015). Mi princesito. Bartzelona: Bellaterra.

Olga de Dios, (2013). Monstruo rosa: Zaragoza: Apila.

Tomie de Paola, (1979). Oliver Button es una nena. Leon: Everest.

Sylvia Rivera, (2012). Piratrans Carabarco. Asociación de transexuales de Andalucía La Calle.

Michael Hall, (2015). Red a crayon's story. Greenwillow Books.

Emily Hughes, (2014).Salvaje. Bartzelona: Libros del zorro rojo.

Greg Mcgoon, (2015). The royal heart. Kalifornia: Pelekinesis.

Nacho Donoso eta Rita Bailón, (2015). Trans Bird. Madril: Opera prima.

\section{Haurrentzako laburmetrai gomendagarriak}

Mobile: $\mathrm{https}: / / \mathrm{www}$.youtube.com/watch?v=Z2EftZ3wkmM Leevi Lemmety (2010).

http://www .rainbowproject.eu/material/es/mobile.htm

Papa's boy: https://www.youtube.com/watch?v=vTmUpQbJ_HI Verena Fels (2010).

http://www.rainbowproject.eu/material/es/papas_boy.htm

\section{Gurasoentzako laburmetrai gomendagarriak}

El vestido rosa: $h t t p s: / / w w w . y o u t u b e . c o m / w a t c h ? v=J M a k y d i 0 p 7 o$ Escandalo films (2008).

How to be a girl: https://www.youtube.com/watch?v=9VEICokBKN0 Marlo Mack, (2014).

\section{Guraso eta irakasleentzako dokumentalak}

Sé quién soy: https://www.youtube.com/watch?v=V1dd8wUX7-U Los reporteros, (2014).

El sexo sentido: https://www.youtube.com/watch?v=PoJLRuS5D0U Documentos TV (2014).

From Lucas to Luus: https://www.youtube.com/watch?v= 7B5HU0gUG-Y Charlotte Hoogakker, rainbow project (2005).

Holly Siz-The light: https://www.youtube.com/watch?v= Cf79KXBCIDg Holly Siz (2013). 
Transexualitatea bizi duten haurren errealitatea: https://www. facebook.com/ChrysallisEuskalHerria/videos/vb.634727083338095 /759837227493746/?type=2\&theater Aingeru Mayor (2015).

Niñas con pene y niños con vulva: https://www.youtube.com/ watch?v=bN2Zl3hiNXg Aingeru Mayor (2015).

Descubrir la niña: http://chrysallis.org.es/descubrir-a-la-nina/ Natalia Aventín (2014).

\section{Guraso zein irakasleentzako film gomendagarriak}

Ma vie en rose: $h$ ttp://cinegaygratis.blogspot.com.es/2015/06/mi-vidaen-rosa.html Alain Berliner (1997).

Tomboy: http://streamin.to/ayle19vkj001 Céline Sciamma (2011).

\section{Erakunde gomendagarriak}

Chrysallis: http://chrysallis.org.es/

Fundación Daniela: http://www.fundaciondaniela.org/

Berdindu: http://www.gizartelan.ejgv.euskadi.eus/r45-berdhome/es/

Aldarte: http://www.aldarte.org/es/default.asp

\section{Material gomendagarria}

Steilas (2015). Genero eta aniztasun sexualerako gidaliburua. http:// www.steilas.eus/files/2015/05/Genero-eta-aniztasun-sexualerako-GIDA. -STEILAS.2015.pdf

\section{Jarduera batzuk}

Cómo educar en la diversidad afectiva, sexual y personal en educación infantil, orientaciones prácticas liburutik egokituta (Sánchez-Sáinz, M., 2010): Silueta eta Denek burla egiten diote Melmerri.

Trans* sexualidades. Acompañamiento, factores de salud y recursos educativos liburutik egokitua (Platero, 2015): Estereotipoak apurtzen, Nork erabiltzen du zer? Eta Zer izango da etorkizunean? 


\section{Lan honen prozesuan sortutako jarduerak}

Ni al naiz? Noski: psikomotrizitate saio batean haurrei hankaz gorako munduan sartu direla esango zaie eta hortaz, mutilak nesken jantziekin mozorrotuko dira eta alderantziz. Horretarako generoekin lotutako jantzi estereotipatuak emango zaizkie. Jolasean ibili ondoren, bakoitzari galdetuko zaio: Nor zara zu? Izena esan ondoren, irakasleak galdetuko die ea zer uste duten direla neska ala mutila? Erantzunak seguruenik bat egingo du beraien benetako generoarekin eta irakasleak hori erabiliko du eztabaida sortzeko haurrek ikus dezaten arropak ez duela zerikusirik generoarekin eta norberak erabakitzeko aukera daukala.

Goazen pertsonak asmatzera!!: Aurreko ariketari jarraipena emateko asmoz, haurrei proposatuko diegu pertsonaia berriak asmatzeko. Pertsonaiak ez dira ez neskak ez mutilak izango, bien uztarketa bat baizik. Beraien janzkera probatzen aritu eta gero, bakoitzari eskatuko diogu bere burua aurkezteko, izen berri bat asmatuz eta zer gustatzen zaion eta zer dakien egiten galdetuz. Bukatzean aukera emango diegu irakaslearen laguntzaz antzezpen laburrak egiteko talde txikietan.

Ereduak bilatzen: Irakasleak estereotipoak betetzen ez dituzten pertsonen irudiak eramango ditu ikasgelara, hala nola, ilea oso motz moztuta duten emakumeak, janzkera femeninoa duten mutilak zein pertsona trans* edo androgino ezagunenak. Irakasleak haurrei erakutsiko dizkie eta argazki bakoitza ikusi ostean, galdetuko die ea neska ala mutila den. Seguruenik erantzunak anitzak izango direnez, horrek aukera eskainiko dio eztabaida bat sortzeko. Horretarako irakasleak galdera anitzak egin beharko ditu haurren argudiaketak bultzatzeko.

Sar gaitezen istorioan!!: Melmerren jarduerari jarraipena emateko galderekin amaitu ostean, haurrei hiru taldetan banatzeko proposatuko diegu eta talde bakoitzean 3 haurrek Melmerren papera antzeztuko dute eta gainontzekoek aldiz, klasekideen rola hartuko dute. Komenigarria izango litzateke ikasgelan liderrak egonez gero, Melmer izendatzea, beraien lagunek zer sentitzen duten ikusarazteko. Amaitzerakoan, nola sentitu diren galdetuko diegu eta bazterketak dakarren bakardade eta ezintasunari buruz hitz egingo dugu. Beraiek protagonista izanda haientzat gogorregia izan daitekeela pentsatzen badugu, interesgarria izan daiteke beraiek ezagutzen duten pertsonaia baten kasua aipatzea, hala nola, Bob Esponja.

Aniztasunak aberasten gaitu!: Haurrek normalean desberdina dena okerragoa dela pentsatu ohi dute eta ondorioz, baztertzeko joera izaten dute. Hori ekiditeko asmoz, komenigarria izango litzateke guztiok desberdinak garela ikustea. Horretarako, gure gorputzeko ezaugarriak erabili ditzakegu desberdintasunak agertzeko. Hasiera batean, ezaugarri nabarmenenak edo ikusgarrienak erabili ditzakegu eta gero pixkanaka ezaugarri konkretuagoak landu. Adibidez, altuera edo pisutik has gaitezke, gero ilearen kolorea azter dezakegu, ondoren hortzen tamaina edo begien ko- 
lorea eta azkenik izateko era: alaia, isila, lotsatia, beldurtia, irribarretsua, kantaria... Saiatu beharko gara haur guztien berezitasunak identifikatu eta azaleratzen guztiek ikus dezaten denok dugula desberdin egiten gaituen zerbait. Ondoren, irakasleak galdera desberdinak egin ditzake, hala nola, ile horia dutenek ile gorria dutenek baino besarkada hobeak ematen dituzte? Edo begi berdeak dituztenak begi urdinak baino azkarrago jaten dituzte gailetak? Haurrek baietz erantzunez gero, zergatia galdetuko diegu. Ezetz erantzuten badute aldiz, guk esango diegu, orduan zergatik esaten dugu adibidez, neskek ezin dutela futbolean jolastu edo mutilei ezin zaizkiela panpinak gustatu? Ez al dira besteak bezain zentzugabeko galderak?

Onartze-data: $2017 / 02 / 22$

\begin{abstract}
By the time we are born, we are classified as male or female. Doctors define our gender based on our genitals. From then on, adults treat us in a particular way according to our gender, they don't give us the option to choose. However, gender identity develops throughout life and it doesn't always match with the assigned sex. The early childhood education is very important in this process because this is when children begin to identify their gender. That's why parents' and teachers' attitudes are so important. Given that nowadays this is a rather unknown topic, in this work we will analyze the knowledge teachers has on gender and sex diversity. To do this we will use interviews and questionnaires done to teachers and an observation work in the classroom. Finally, due to the little knowledge on this topic in educational environments too, a list of resources will be offered to early childhood teachers and parents.
\end{abstract}

Keywords: Gender identity, Gender rules, Gender non-conforming, Sex and Gender Diversity, Infant Education.

En el momento en que nacemos, estamos clasificados como hombres o mujeres. Los médicos definen nuestro género basándose en nuestros genitales. A partir de entonces, los adultos nos tratan de una manera particular según nuestro género, no nos dan la opción de elegir. Sin embargo, la identidad de género se desarrolla a lo largo de la vida y no siempre coincide con el sexo asignado. La educación de la primera infancia es muy importante en este pro- 
ceso porque es cuando los y las niñas comienzan a identificar su género. Es por eso que las actitudes de las familias y docentes son tan importantes. Dado que hoy en día este es un tema bastante desconocido, en este trabajo analizaremos los conocimientos que las y los maestros tienen sobre la diversidad de género y sexo. Para ello, utilizaremos entrevistas y cuestionarios hechos al profesorado y un trabajo de observación en el aula. Por último, debido al escaso conocimiento sobre este tema en los entornos educativos, también se ofrecerá una lista de recursos para los y las docentes de la primera infancia y las familias.

Palabras clave: Identidad de género, Normas de género, Disconformidad de género, Diversidad de sexo y género, Educación Infantil

Au moment où nous sommes nés, nous sommes classés comme hommes ou femmes. Les médecins définissent notre sexe en fonction de nos organes génitaux. Dès lors, les adultes nous traitent d'une manière particulière selon notre sexe, ils ne nous donnent pas la possibilité de choisir. Cependant, l'identité de genre se développe tout au long de la vie et elle ne correspond pas toujours au sexe assigné. L'éducation de la petite enfance est très importante dans ce processus parce que c'est quand les enfants commencent à identifier leur genre. C'est pourquoi les attitudes des parents et des enseignants sont si importantes. Étant donné que, de nos jours, ce sujet est plutôt inconnu, nous analyserons les connaissances que les enseignants ont sur la diversité des genres et des sexes. Pour ce faire, nous utiliserons des entretiens et des questionnaires aux enseignants et un travail d'observation en classe. Enfin, en raison du peu de connaissances sur ce sujet dans les milieux éducatifs, une liste de ressources sera offerte aux enseignants et aux parents de la petite enfance.

Mots-clé: l'identité de genre, règles de genre, disconformité de genre, la diversité des sexes et des genres, École maternelle. 


\section{ERREFERENTZIAK}

\section{Liburuak}

Alvarez-Uria, A. (2013). Glosategia. In Castillo, I. eta Retolaza, I. Genero ariketak. Feminismoaren subjektuak. Donostia: EDO!

Becerra, M. eta Melo, O. (2012). Identitdad sexual y desarrollo de la personalidad. AMEI. http://www.waece.org/biblioteca/pdfs/d006.pdf 2016ko azaroaren 3an kontsultatua. Hitzaldi baten ondorioak.

Blaise, M. eta Taylor, A. (2012) Using Queer Theory to Rethink Gender Equity in Early Childhood Education. Young Children. 67(1). 88-96.

Bronfman, A. eta Martínez, I. (1996). La socialización en la escuela: una perspectiva etnográfica. Bartzelona: Paidós.

Butler, J. (2001). El género en disputa. El feminismo y la subversión de la identidad. Bartzelona: Paidós.

Colás-Bravo, P. eta Jiménez-Cortés, R. (2006). Tipos de conciencia de género del profesorado en los contextos escolares. Revista de educación. 340. 415-444.

Coll-Planas, G. (2013). Dibujando el género. Bartzelona: Egales.

Crawford, M. eta Chaffin, R. (1997). The Meanings of Difference: Cognition in Social and Cultural Context. In Caplan, P. J.; Crawford, M.; Hyde, J. S.; Richardson, J. T. E. Gender Differences in Human Cognition. Oxford: Oxford University Press.

Gallardo, F. eta Escolano, V. (2009). Informe Diversidad Afectivo-Sexual en la Formación de Docentes: Evaluación de Contenidos LGTB en la Facultad de C.C.E.E. de Málaga. Malaga: CEDMA.

Green, F.J. eta Friedman, M. (2013). Buscando el final del arcoíris: una exploración de las prácticas de crianza desde la fluidez de género. Bartzelona: Bellaterra.

Halberstam, J. (2008). Masculinidad femenina. Bartzelona: Egales.

López, F. (1984). La adquisición del rol y la identidad sexual: función de la familia. Infancia y Aprendizaje 26. 65-75.

Malavé, Z. (2012). La equidad de género de escuela elemental: percepción de los maestros. Puerto Rico: Universidad del Turabo. Doktorego tesia.

Mayor, A. (2015). Niñas con pene y niños con vulva: comprender para poder apoyar. https://www.youtube.com/watch? $\mathrm{v}=\mathrm{x} 0 \mathrm{VDdR} 0 \mathrm{HcuM}$ 2016ko azaroaren 3 an kontsultatua. Hitzaldia Gorlizeko ikastetxe publikoan.

Mcdonough, K. (2007) The «futures» of queer children and the common School Ideal. Journal of Philosophy of Education. 41(4). 795-810.

Menvielle, E. (2003). Conductas de género variantes en la infancia: un nuevo paradigma clínico.http://www.psygnos.net/biblioteca/articulos/infancia/040728_ menvielle.htm 2016ko azaroaren 3an kontsultatua.

Olabuénaga, J.I. (1989). La descodificación de la vida cotidiana: Métodos de la investigación cualitativa. Bilbo: Deustoko Unibertsitatea.

Paechter, C. (2007). Being BOYS, Being GIRLS: Learning masculinities and femininities. Maidenhead: Open University.

Platero, R.L. (2014). Trans*sexualidades: acompañamiento, factores de salud y recursos educativos. Bartzelona: Bellaterra. 
Platero, R.L. (2015) Antes los niños y las niñas que rompían las normas eran mariquitas o marimachos. http://www.eldiario.es/catalunya/Lucas-Platero-rompian-mariquitasmarimachos_0_344715843.html 2016ko azaroaren 3an kontsultatua.

Romero, A. eta Abril, P. (2008). Género y la formación del profesorado en los estudios de Educación Infantil. Revista electrónica interuniversitaria de formación del profesorado. 11(3). 43-51.

Sánchez-Sáinz, M. (2010). Cómo educar en la diversidad afectiva, sexual y personal en la educación infantil: orientaciones prácticas. Madril: Catarata.

Sánchez, T. (2009) Desarrollo de la Identidad de Género desde una Perspectiva Psico-Socio-Cultural: Un Recorrido Conceptual. Revista Interamericana de Psicología. 43(2). 250-259.

Talburt,S. eta Steinberg, S. (2005). Pensando queer: sexualidad, cultura y educación. Bartzelona: Graó.

- (2013). Genero erregulazioak. In Castillo, I. eta Retolaza, I. Genero ariketak. Feminismoaren subjektuak. Donostia: EDO! 249-276. 